\title{
Germination and allometry of the native palm tree Euterpe edulis compared to the introduced E. oleracea and their hybrids in Atlantic rainforest
}

\author{
Tiberio, FCS. ${ }^{a *}$, Sampaio-e-Silva, TA. ${ }^{a}$, Dodonov, . $^{a}$, Garcia, VA. ${ }^{b}$ and Silva Matos, DM. ${ }^{a}$ \\ áLaboratório de Ecologia e Conservação, Departamento de Botânica, \\ Universidade Federal de São Carlos - UFSCar, Rod. Washington Luís, Km 235, SP 310, São Carlos, SP, Brazil

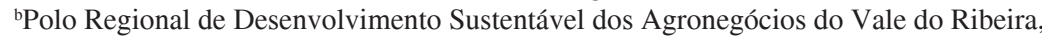 \\ Agência Paulista de Tecnologia dos Agronegócios, SAA-SP, Rod. Regis Bittencourt, Km 460, Pariquera-Açu, SP, Brazil \\ *e-mail: nandatiberio@gmail.com \\ Received November 30, 2011 - Accepted February 14, 2012 - Distributed November 30, 2012
}

(With 1 figure)

\begin{abstract}
Palms are distinctive plants of tropics and have peculiar allometric relations. Understanding such relations is useful in the case of introduced species because their ability to establish and invade must be clarified in terms of their responses in the new site. Our purpose was to assess the survival and invasive capacity of an introduced palm species in the Atlantic rainforest, Euterpe oleracea Mart., compared to the native Euterpe edulis Mart. and to the hybrids produced between the two species. Considering this, we compared the allometry in different ontogenetic stages, the germination rates, and aspects of the initial development. The ontogenetic stages proposed for both Euterpe illustrated the growth patterns described for palm trees. E. oleracea and hybrids adjusted to the geometric similarity allometric model, while E. edulis presented a slope greater than would be expected considering this model, indicating a greater height for a given diameter. E. oleracea showed the same amount of pulp per fruit as E. edulis and a similar initial development of seedlings. The main differences observed were a lower germination rate and a faster height gain of E. oleracea seedlings. We conclude that E. oleracea, which is similar to E. edulis in aspects of allometry, development, seed and seedling morphology, may be an important competitor of this native palm tree in the Atlantic Forest.
\end{abstract}

Keywords: palms, hybridization, growth model, species introduction.

\section{Germinação e alometria de Euterpe edulis comparadas à palmeira introduzida Euterpe oleracea e seus híbridos na floresta Atlântica}

\begin{abstract}
Resumo
Palmeiras são plantas características dos trópicos que apresentam relações alométricas peculiares. Compreender tais padrões pode ser útil no caso de espécies introduzidas, uma vez que sua habilidade de estabelecimento e invasão deve ser esclarecida em relação as suas respostas à nova localidade. Nosso propósito foi compreender a sobrevivência e a capacidade de invasão de uma palmeira introduzida na floresta Atlântica, Euterpe oleracea Mart. (açaizeiro) comparada à palmeira nativa Euterpe edulis Mart. (juçara), também considerando seus híbridos. Para isso comparamos suas relações alométricas em estádios ontogenéticos, sua germinação e seu desenvolvimento inicial. Os estádios ontogenéticos propostos para ambas as Euterpe ilustraram os padrões de crescimento esperados para palmeiras. E. oleracea e híbridos apresentaram-se sob o modelo alométrico de similaridade geométrica e E. edulis apresentou inclinação maior do que este modelo. E. oleracea produziu a mesma quantidade de polpa por fruto que E. edulis. As principais diferenças observadas foram menor taxa de germinação e maior velocidade de crescimento em altura para as plântulas de E. oleracea. Em conclusão, nossos resultados indicam que E. oleracea, sendo similar a E. edulis em termos de alometria, desenvolvimento e morfologia de sementes e plântulas, pode ser um importante competidor para a espécies nativa na Floresta Atlântica.
\end{abstract}

Palavras-chave: palmeiras, hibridização, modelo de crescimento, introdução de espécies. 


\section{Introduction}

Palms are typical exponents of tropical plants and play an important role in natural and human communities (Henderson et al., 1995; Tomlinson, 2006). They have impressive development and and great ecological importance, especially as food resources. After their fruit are eaten and their seeds land on the ground, development must start quickly because most of them do not form soil seed banks (Henderson et al., 1995). Palms are also unique in the way they build long, tall lived trees entirely by primary growth, i.e., all tissues result directly from the activity of shoot and apical meristems, ensuring minimum susceptibility to fire, pathogens and wind damage (Tomlinson, 2006). This growth results in a unique allometric pattern, where height may increase almost unlimitedly by the plant diameter when compared to other tree species (Rich, 1987).

Allometric patterns of plants result from the balance of investments in support structures and photosynthetic biomass (Niklas, 1995; Niklas, 2004). Aerial parts of a plant are submitted to forces like gravity and wind, so they have to allocate energy to support themselves while growing, and must also provide photosynthetic structures to ensure biomass assimilation. Allometric relationships may change during the development of plant individuals, with each ontogenetic stage presenting a different allometry between height and diameter, as a response to dissimilar environmental, morphological and physiological conditions experienced by individuals from different stages (Gatsuk et al., 1980; Weiner, 2004).

It is already recognized that non-indigenous species are intensively dispersed for economic purposes (Levine et al., 2003), and this applies to many palm trees (Holmquist et al., 2010; Henderson et al., 1995; Svenning, 2002; Meyer et al., 2008). Although the establishment of plant populations outside their natural range of occurrence is not common (Richardson et al., 2000), some of these populations can become successfully established (Mooney and Cleland, 2001) and modify ecosystem functions, as well as the availability or quality of resources and space (Levine et al., 2003). Therefore, assessment of morphological traits can also be a tool for evaluating the status of non-indigenous species, since phenotypic plasticity indicates its ability to adapt to different environments (Tucic et al., 2006).

Amongst many examples from Brazil, two ecological and economically important palm trees with dissociated occurrence are now being cultivated in the same environments: Euterpe oleracea, originating from the Amazon rainforest, has been cultivated on a large scale in the Atlantic Rainforest, the natural habitat of the congener palm E. edulis, since the late 1970s. Fruit from both species is important in terms of food resources for birds in their original areas (Galetti et al., 1999; Moegenburg and Levey, 2003; Genini et al., 2009). When co-existing, these palms produce hybrids (Bovi et al., 1987a; Campos et al., 1991).

The objective of this study was to assess the phenotypic plasticity of the introduced species E. oleracea and its hybrids with the native E. edulis in the Atlantic rainforest.
Considering this, we compared their ontogenetic development, allometry, seed and seedling characteristics and germination. Since the two species have similar morphology when occurring in their natural ranges (Henderson et al., 1995), we expected similar allometry and germination rates when co-occuring in the same environment. This would indicate the potential competition between the two species and the potential of E. oleracea to invade the Atlantic forest.

\section{Methods}

Study area: We sampled the populations of Euterpe edulis, E. oleracea and their hybrids in Carlos Botelho State Park (CBSP), located in south-eastern Brazil, with a total area of 37,644 ha and the altitudes between 20 and $1000 \mathrm{~m}$ (SÃO PAULO, 2008). The vegetation is a typical tropical rainforest with Af climate (sensu Köppen 1948) and average rainfall from 1700 to $2400 \mathrm{~mm}$ (SÃO PAULO, 2008). In 1970, E. oleracea was planted in a floodplain area within the Park.

Seeds were collected from plants located in the experimental plantation of Agência Paulista de Tecnologia dos Agronegócios (APTA) (Agrarian Technology Agency of São Paulo State) in the municipality of PariqueraAçu, São Paulo, south-eastern Brazil. The objective of these E. oleracea plantations was to produce hybrids with E. edulis to improve the development of palm heart (Bovi et al., 1987a).

Study species: the jussara palm, E. edulis, occurs naturally in the Atlantic rainforest on the Brazilian coast and may also be found in Paraguay and Argentina (Henderson et al., 1995). It has an arborescent habit, with a single stem, and may reach $15 \mathrm{~m}$ in height in the study site. It produces globular purple-black fruit with $1-1.4 \mathrm{~cm}$ in diameter (Henderson et al., 1995). This species has been under threat due to indiscriminate exploitation, mostly of which is illegal, since the second half of the twentieth century (Silva Matos and Bovi, 2002). As it produces a single stem and does not resprout, the plant dies when the palm heart is extracted. Currently, the presence of E. edulis is restricted to remote areas of the Atlantic rainforest (Silva Matos and Bovi, 2002).

The assaí palm, E. oleracea, is commonly found along the Amazon river basin in the North of Brazil, and therefore it is geographically distant from E. edulis in the Atlantic rainforest (Henderson et al., 1995). E. oleracea produces multiple stems and can reach 12-20 meters in height. Its apical meristem is also exploited to produce palm heart (Henderson et al., 1995). It bears purple-black globular fruits with 1-2 cm in diameter (Henderson et al., 1995; Lorenzi et al., 2004) which are harvested for assaí cream production. The palm heart from E. oleracea has a lower quality than its congener but, as a plant with multiple stems, the production may be higher and the plant is not necessarily killed during palm heart extraction as occurs with E. edulis. The better quality of its palm heart, the increasing demand of the consumer market and the 
scarcity of E. edulis made it one of the most expensive palm hearts in Brazil.

Experimental production of hybrids between E. edulis and E. oleracea started after E. oleracea was introduced into the Atlantic rainforest (Bovi et al., 1987a). The main purpose was to increase the production of high-quality palm hearts by combining the palm heart quality of E. edulis and the presence of multiple stems of E. oleracea (Bovi et al., 1987a; Campos et al., 1991). Although promising results were obtained in these experiments, data on hybrids produced under non-mediated conditions have been unavailable until present.

Data sampling. At CBSP, we measured the height and basal diameter of all individuals (except seedlings) of E. edulis, E. oleracea, and their hybrids in 35 contiguous plots $(10 \times 10 \mathrm{~m})$. Seedlings were sampled in sub-plots $(2 \times 2 \mathrm{~m})$ within each $100 \mathrm{~m}^{2}$ plot. As each stem in the E. oleracea clumps is able to reproduce, we counted each stem as a distinctive individual. Individuals from each population were divided into ontogenetic stages according to their morphology (Gatsuk et al., 1980; Silva Matos et al., 1999). Taking this into account, besides height and diameter, we also observed leaf and leaflet shape, stem exposure, and presence of inflorescences, infrutescences or signs of previous reproduction such as the presence of scars on stems.

At APTA, we randomly selected 10 individuals of E. edulis, E. oleracea, and their hybrids, from which we collected one infrutescence and obtained its total fruit mass. We arbitrarily selected 50 pieces of mature fruit per infrutescence and obtained the mass and diameter of each fruit and seed using a digital scale and a digital caliper. Finally, for the experiment on seed germination, each seed was sown in compost soil and watered daily under greenhouse conditions. Due to differences in the time of fruiting, seeds of E. edulis were planted in April, 2010 and seeds of E. oleracea were planted in June, 2010. We followed the germination and seedling growth for eight months. After the seeds germinated, we removed the seedlings and measured their diameter, height and the wet and dry weight $\left(70{ }^{\circ} \mathrm{C}\right.$ for 48 hours) of their shoots and roots. Germination rate was considered as the percentage of seeds that germinated during the study.

Data analysis: We classified the individuals into ontogenetic stages, which we defined according to the distributions of height and diameter, their coefficient of variation $(\mathrm{CV})$, and also their morphological characteristics. Depending on the normality of data, we used either Student's t-test or Mann-Whitney to test for differences between stages and populations considering the mean or median diameter and height. The analyses were performed in the Past 2.05 statistical program (Hammer et al., 2010).

The allometry in terms of diameter and height was tested using the model (Equation 1)

$\mathrm{H}=b . \mathrm{D}^{a}$

(McMahon and Kronauer, 1976), where $\mathrm{H}$ is the plant height, $\mathrm{D}$ is the diameter, $b$ is the intersection value, and $a$ is the slope value that represents the proportionality between the two variables (McMahon and Kronauer, 1976). Allometric relationships between stem height and diameter usually follow one of the three different models: the geometric, elastic, and stress similarity, characterized by their slope values (respectively 1.0, 0.66, and 0.5) (McMahon and Kronauer, 1976; Dodonov et al., 2011). We calculated Pearson's correlation coefficient and performed a standardized major axis regression (SMA) (Warton et al., 2006) between $\log \mathrm{H}$ and $\log \mathrm{D}$ for the pooled data and for each ontogenetic stage separately, for the two species and their hybrids. We then compared the obtained slopes to the values expected from the three allometric models, and evaluated the differences in the slopes between populations and between stages of each population. We used a likelihood ratio test (Warton et al., 2006) for theses comparisons. We used the smatr package (Warton, 2007) in R (R Development Core Team, 2011) for the SMA regression and for the comparisons.

For the germination and seedling comparisons, we first used a permutation t test, in Past 2.05 (Hammer, 2010), to compare the number of germinated seedlings per parental plant and the weight and amount of fruit per infrutescence between the two species and their hybrids. We then used a permutation analysis of variance (ANOVA) (Manly, 2007) to check for homogeneity of means between the seeds and seedlings originated from different parental plants within each species (intra-specific comparisons). We performed this comparison for the following variables: fruit and seed weight and diameter and pulp weight (calculated as fruit weight - seed weight), for all fruit and for the germinated fruit only; root, shoot and total weight of the seedlings (wet and dry); shoot:root ratio (wet weight only); and water proportion, calculated as ( 1 - wet weight / dry weight). Afterwards, we compared the two species for the same variables, by means of restricted permutation tests (Manly, 2007). In these restricted permutations, all seedlings originated from the same parental plant were permuted together, and the mean difference between the two species was compared to the distribution of differences in 5,000 permutations. We used Bonferroni correction (SISA 2011) to correct multiple comparisons.

We calculated Pearson's correlation coefficient between the dry weight of each seedling and the original weight of its former seed and between the height and diameter of seedling stems, and assessed their significance by means of restricted permutations. Permutation tests for significance of regression and correlation coefficients consider the random rearranging the pairs of variables (Manly, 2007). To account for the non-independence, we rearranged the variables only between seedlings originating from the same parental plant. Finally, we performed SMA regressions between $\log \mathrm{H}$ and $\log \mathrm{D}$ for seedlings of the two species, and compared them with a likelihood ratio test (Warton et al., 2006) in the smatr package (Warton, 2007) in R ( $R$ Development Core Team, 2011). We performed all the restricted permutation analyses and the permutation ANOVA in R (R Development Core Team, 
2011), and the code developed for this is available from the authors on request.

\section{Results}

We determined five ontogenetic stages for both species of Euterpe and hybrids: (i) seedling: individual with up to three leaves with palmate leaflets; (ii) sapling: individual with pinnate leaves, without exposed stem; (iii) juvenile: individual with pinnate leaves and exposed stem; (iv) immature: individual with pinnate leaves, exposed stem and with no signs of reproductive events; (v) adult: individual with pinnate leaves, exposed stem, and signs of reproduction such as infrutescences or their scars on the stem. Mean height and diameter were significantly different between all ontogenetic stages of the three populations (Table 1). Younger stages had higher CVs for diameter, and older stages had higher CVs for height (Table 1).

All three populations presented high Pearson's determination coefficients $\left(\mathrm{R}^{2}\right)$ between the log height and $\log$ basal diameter for the pooled data. The SMA regression for E. edulis populations presented slopes higher than expected for geometric similarity (Table 2), while E. oleracea and hybrids fitted the geometric similarity model (Table 2).

Saplings and juveniles of E. edulis fitted to the geometric similarity model; the immatures of this species, however, did not fit to any of the three models, presenting a slope much greater than would be expected under geometric similarity (Table 2). Hybrids presented a geometric similarity model for saplings, while juveniles could be described by both geometric and elastic similarity models (Table 2). Likewise, saplings and juveniles of E. oleracea fitted to both the geometric and the elastic similarity models (Table 2).

The likelihood ratio test indicated significant differences between the three species $(\mathrm{LR}=11.96, \mathrm{p}=0.002)$. However, after an a posteriori analysis, we identified that this difference occurs only between hybrids and E. oleracea $(\mathrm{LR}=4.49$, $\mathrm{p}=0.03)$ and between hybrids and E. edulis $(\mathrm{LR}=20.98$, $\left.\mathrm{p}=4.63 \times 10^{-6}\right)$. There was no difference between $E$. edulis and E. oleracea $(\mathrm{LR}=0.45, \mathrm{p}=0.49)$, as also observed by the overlap in the $95 \%$ confidence intervals of these two species. Analyzing each population separately, we found different slopes between the ontogenetic stages of E. edulis $\left(\mathrm{LR}=43.15, \mathrm{p}=4.25 \times 10^{-10}\right)$, but not between the stages of E. oleracea and the stages of hybrids (E. oleracea, $\mathrm{LR}=1.16, \mathrm{p}=0.56$; hybrids $\mathrm{LR}=3.08, \mathrm{p}=0.21$ ).

For both species and their hybrids, we observed significant differences between the individuals of the same species with regards to the size of their fruits and seeds (permutation $p<0.001$ in all analyses), indicating large intra-species variability. Infrutescenses of E. edulis were four times heavier than those of E. oleracea $(2222 \pm 961 \mathrm{~g}$ and $526 \pm 260 \mathrm{~g}$ respectively, permutation $\mathrm{p}<0.0001)$ and had five times more fruits $(1667 \pm 708$ and $329 \pm 142$, permutation $\mathrm{p}<0.0001)$. The fruits and seeds of E. oleracea were slightly larger than of E. edulis (permutation p < 0.02), but the pulp weight did not vary significantly between

Table 1. Diameter and height distributions of ontogenetic stages of E. edulis, E. oleracea and hybrids at Carlos Botelho State Park (CBSP), SP, Brazil. In each population, different superscript letters indicate significant difference between distributions according to a t-test or a Mann-Whitney test, considering $p<0.05$. Letters used for height and for diameter are independent of each other. We only considered ontogenetic stages that had sufficient data for the analysis. Min: minimum, max: maximum, avg: average, sd: standard deviation, cv: coefficient of variation.

\begin{tabular}{|c|c|c|c|c|c|c|c|c|c|c|c|c|c|}
\hline \multirow{2}{*}{ Population } & \multirow{2}{*}{$\begin{array}{c}\text { Ontogenetic } \\
\text { stage }\end{array}$} & \multirow{2}{*}{$\mathbf{N}$} & \multirow{2}{*}{$\begin{array}{l}\text { Relative } \\
\text { frequency }\end{array}$} & \multicolumn{5}{|c|}{ Diameter (cm) } & \multicolumn{5}{|c|}{ Height } \\
\hline & & & & $\min$ & $\max$ & avg & sd & cv & $\min$ & $\max$ & avg & sd & cv \\
\hline \multirow[t]{5}{*}{ E. edulis } & Seedling & 3 & 0.18 & - & - & - & - & - & - & - & - & - & - \\
\hline & Sapling & 240 & 0.60 & 0.21 & 3.41 & $0.93^{\mathrm{a}}$ & 0.54 & 0.58 & 0.01 & 0.29 & $0.12^{\mathrm{a}}$ & 0.06 & 0.51 \\
\hline & Juvenile & 49 & 0.12 & 2.11 & 6.33 & $3.83^{\mathrm{b}}$ & 1.18 & 0.31 & 0.30 & 0.98 & $0.48^{b}$ & 0.19 & 0.39 \\
\hline & Immature & 34 & 0.08 & 5.99 & 19.75 & $12.06^{\mathrm{c}}$ & 3.98 & 0.33 & 1.00 & 9.00 & $3.85^{\mathrm{c}}$ & 2.22 & 0.58 \\
\hline & Adult & 2 & 0.005 & - & - & - & - & - & - & - & - & - & - \\
\hline \multirow[t]{5}{*}{ E. oleracea } & Seedling & 0 & - & - & - & - & - & - & - & - & - & - & - \\
\hline & Sapling & 35 & 51.47 & 0.69 & 3.97 & $1.77^{\mathrm{a}}$ & 0.87 & 0.49 & 0.05 & 0.29 & $0.21^{\mathrm{a}}$ & 0.07 & 0.31 \\
\hline & Juvenile & 25 & 36.76 & 1.74 & 9.24 & $5.25^{\mathrm{b}}$ & 1.94 & 0.37 & 0.31 & 0.97 & $0.43^{\mathbf{b}}$ & 0.21 & 0.48 \\
\hline & Immature & 7 & 10.29 & 6.05 & 23.89 & 10.83 & 6.20 & 0.57 & 1.23 & 4.50 & 1.39 & 1.41 & 1.01 \\
\hline & Adult & 1 & 1.47 & - & - & - & - & - & - & - & - & - & - \\
\hline \multirow[t]{5}{*}{ Hybrids } & Seedling & 0 & - & - & - & - & & & - & - & - & - & - \\
\hline & Sapling & 35 & 48.61 & 0.86 & 1.88 & $1.32^{\mathrm{a}}$ & 0.67 & 0.51 & 0.03 & 0.29 & $0.18^{\mathrm{a}}$ & 0.06 & 0.36 \\
\hline & Juvenile & 32 & 44.44 & 2.75 & 8.73 & $5.08^{\mathrm{b}}$ & 1.69 & 0.33 & 0.30 & 0.88 & $0.44^{b}$ & 0.16 & 0.35 \\
\hline & Immature & 5 & 6.94 & 5.36 & 14.33 & 12.10 & 3.43 & 0.28 & 1.01 & 3.75 & 2.00 & 1.09 & 0.55 \\
\hline & Adult & 0 & - & - & - & - & - & - & - & - & - & - & - \\
\hline
\end{tabular}


Table 2. Sample size $(\mathrm{N})$, regression data and allometric model for the pooled data and ontogenetic stages of E. edulis, E. oleracea and hybrids at Carlos Botelho State Park (CBSP), SP, Brazil, according to a Standardize Major Axis regression. We only considered ontogenetic stages that had sufficient data for the analysis.

\begin{tabular}{|c|c|c|c|c|c|c|c|c|}
\hline \multirow[b]{2}{*}{ Population } & \multirow[b]{2}{*}{ Stage } & \multirow[b]{2}{*}{$\mathbf{N}$} & \multicolumn{5}{|c|}{ SMA Regression } & \multirow{2}{*}{$\begin{array}{c}\text { Allometric } \\
\text { model }\end{array}$} \\
\hline & & & $\begin{array}{c}\text { Slope } \\
a \\
\end{array}$ & $\begin{array}{c}\text { Lower } \\
\text { limit }\end{array}$ & $\begin{array}{c}\text { Upper } \\
\text { limit }\end{array}$ & $\mathbf{R}^{2}$ & p-value & \\
\hline \multirow[t]{4}{*}{ E. edulis } & Pooled data & 323 & 1.16 & 1.12 & 1.20 & 0.89 & $<0.05$ & None \\
\hline & Sapling & 240 & 0.94 & 0.86 & 1.02 & 0.57 & $<0.05$ & Geometric \\
\hline & Juvenile & 49 & 1.11 & 0.95 & 1.30 & 0.70 & $<0.05$ & Geometric \\
\hline & Imature & 34 & 1.82 & 1.57 & 2.09 & 0.84 & $<0.05$ & None \\
\hline \multirow[t]{4}{*}{ E. oleracea } & Pooled data & 67 & 1.09 & 0.98 & 1.19 & 0.80 & $<0.05$ & Geometric \\
\hline & Sapling & 35 & 0.82 & 0.69 & 0.98 & 0.41 & $<0.05$ & Geometric/Elastic \\
\hline & Juvenile & 25 & 0.88 & 0.63 & 1.22 & 0.50 & $<0.05$ & Geometric/Elastic \\
\hline & Imature & 7 & - & - & - & - & - & - \\
\hline \multirow[t]{4}{*}{ Hybrids } & Pooled data & 72 & 0.98 & 0.89 & 1.08 & 0.84 & $<0.05$ & Geometric \\
\hline & Sapling & 35 & 1.04 & 0.82 & 1.32 & 0.53 & $<0.05$ & Geometric \\
\hline & Juvenile & 32 & 0.81 & 0.65 & 1.02 & 0.62 & $<0.05$ & Geometric/Elastic \\
\hline & Imature & 5 & - & - & - & - & - & - \\
\hline
\end{tabular}

Table 3. Comparisons between fruits, seeds and seedlings of E. edulis, E. oleracea and their hybrids (mean \pm SD). Significance tests refer only to comparisons between E. edulis and E. oleracea. Their hybrids were significantly different $(p=0.0002)$ from both species for all characteristics. Significance tests performed by restricted permutation, significant differences highlighted in bold.

\begin{tabular}{|c|c|c|c|c|c|}
\hline \multirow{2}{*}{ Variable } & \multirow{2}{*}{ E. edulis } & \multirow{2}{*}{ E. oleracea } & \multirow{2}{*}{ Hybrids } & \multicolumn{2}{|c|}{$p($ E. edulis $=$ E. oleracea $)$} \\
\hline & & & & Uncorrected & Bonferroni- corrected \\
\hline \multicolumn{6}{|l|}{ Fruits and seeds } \\
\hline Fruit diameter (mm) & $12.74 \pm 0.79$ & $13.64 \pm 0.77$ & $8.10 \pm 0.78$ & 0.0026 & 0.0035 \\
\hline Fruit weight (g) & $1.34 \pm 0.24$ & $1.59 \pm 0.26$ & $0.33 \pm 0.15$ & 0.0114 & 0.0155 \\
\hline Seed diameter $(\mathrm{mm})$ & $11.45 \pm 0.79$ & $12.26 \pm 0.77$ & $5.63 \pm 0.83$ & 0.0026 & 0.0035 \\
\hline Seed weight (g) & $1.02 \pm 0.19$ & $1.23 \pm 0.22$ & $0.14 \pm 0.11$ & 0.0060 & 0.0082 \\
\hline Pulp weight (g) & $0.32 \pm 0.08$ & $0.36 \pm 0.08$ & $0.20 \pm 0.06$ & 0.1432 & 0.1949 \\
\hline \multicolumn{6}{|l|}{ Seedlings } \\
\hline Stem wet weight $(\mathrm{g})$ & $0.81 \pm 0.23$ & $0.88 \pm 0.44$ & n.a. & 0.3128 & 1.0000 \\
\hline Root wet weight (g) & $0.50 \pm 0.16$ & $0.39 \pm 0.22$ & n.a. & 0.0134 & 0.0734 \\
\hline Total wet weight (g) & $1.31 \pm 0.36$ & $1.27 \pm 0.61$ & n.a. & 0.7280 & 1.0000 \\
\hline Stem dry weight (g) & $0.24 \pm 0.07$ & $0.26 \pm 0.13$ & n.a. & 0.5802 & 1.0000 \\
\hline Root dry weight (g) & $0.15 \pm 0.04$ & $0.11 \pm 0.07$ & n.a. & 0.0018 & 0.0099 \\
\hline Total dry weight (g) & $0.39 \pm 0.10$ & $0.37 \pm 0.18$ & n.a. & 0.3810 & 1.0000 \\
\hline Stem:root ratio & $1.66 \pm 0.43$ & $2.53 \pm 1.16$ & n.a. & 0.0002 & 0.0011 \\
\hline Water proportion & $0.70 \pm 0.04$ & $0.70 \pm 0.17$ & n.a. & 0.9988 & 1.0000 \\
\hline
\end{tabular}

the species (permutation $\mathrm{p}=0.19$ ) (Table 3 ). The results were the same for the analysis considering all fruits and considering only the fruits that germinated. Fruits and seeds of hybrids were significantly smaller than both other species for all variables ( $p=0.0002$, Table 3$)$.

The percentage of germinated seeds was higher for E. edulis than for E. oleracea (mean \pm SD per individual: $66.0 \pm 17.2 \%$ for E. edulis, $13.0 \pm 8.1 \%$ for E. oleracea; permutation $\mathrm{p}<0.0001)$. None of the hybrid seeds germinated, however 17 seedlings of E. oleracea, originated from six different individuals, they presented abnormal leaf forms and leaflet numbers ( 1 to 6 leaflets), unlike $E$. edulis (always 6 or 8 leaflets) and E. oleracea (always 2 leaflets). Probably these seedlings originated from the breeding of E. edulis and E. oleracea (see Figure 1).

When comparing seedlings originating from different parental plants, we observed significant differences for all features in seedlings from $E$. edulis and for no features in seedlings from E. oleracea. Thus, the morphometry of seedlings of E. oleracea seems to be more homogeneous between parental plants than observed for $E$. edulis. There were significant differences between the two species only 

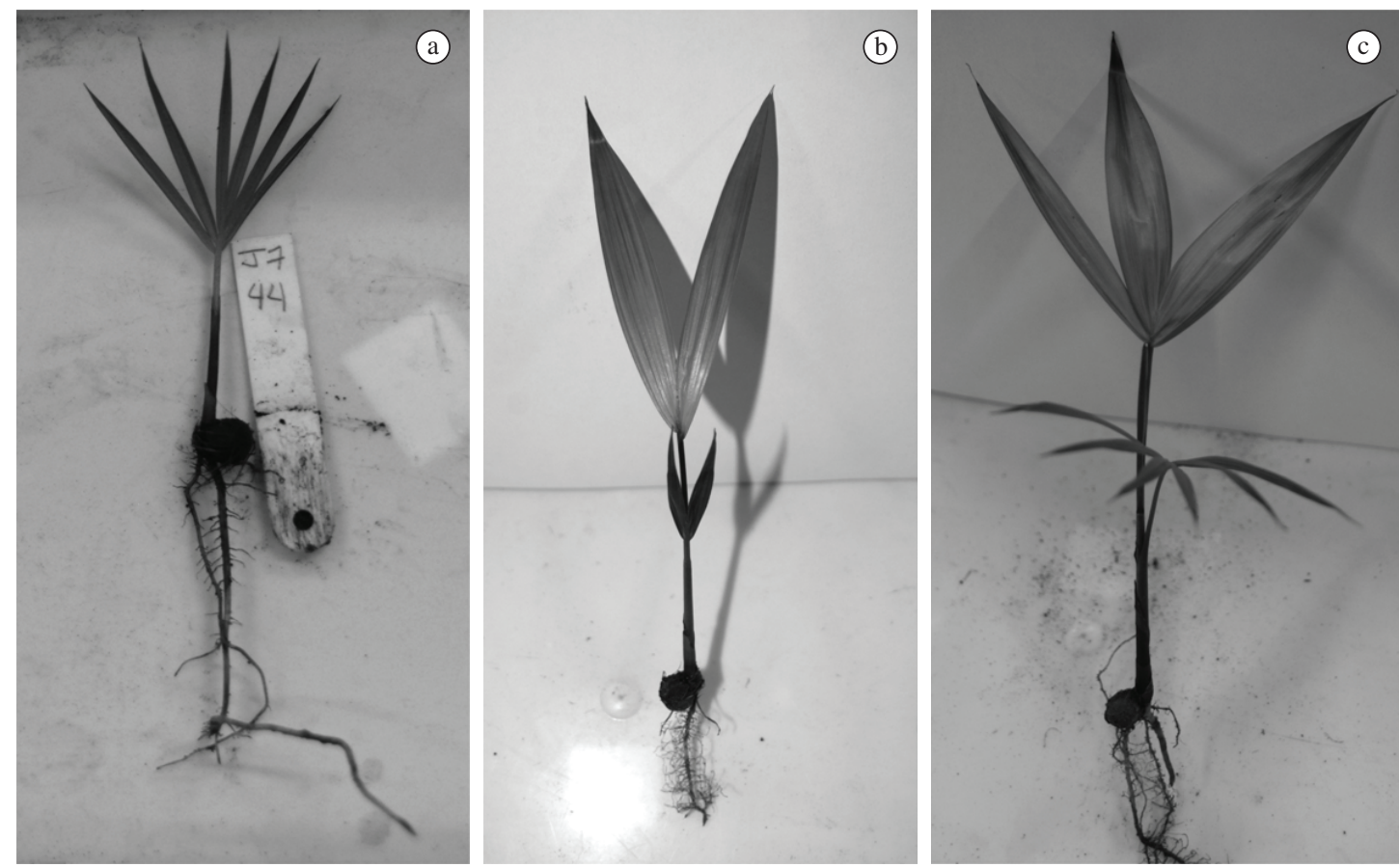

Figure 1. Seedling leafs of (a) E. edulis, (b) E. oleracea and (c) hybrids between E. edulis and E. oleracea. Seedlings considered hybrids emerged from seeds of E. oleracea and presented a variable number of leaflets (1-6). For more information see text.

for dry root weight, which was slightly greater in seedlings of $E$. edulis (permutation $\mathrm{p}=0.01$ ), while the shoot:root ratio was greater for E. oleracea (permutation $\mathrm{p}=0.001$ ) (Table 3). The shoot and the total weight, as well as water proportion, did not vary between the two species (Table 3).

The final weight of seedlings was correlated with original seed weight for E. edulis $(\mathrm{r}=0.55, \mathrm{p}=0.0002)$, but not for E. oleracea $(r=0.23, p=0.07)$. We observed significant correlations between the height and diameter of seedlings for both species, but the regression slope was significantly higher for E. olearacea (E. edulis: $\mathrm{r}=0.39$, slope $=1.1 ;$ E. oleracea $: \mathrm{r}=0.30$, slope $=1.8 ; \mathrm{LR}=7.8$, $p=0.005$; Figure 1).

\section{Discussion}

The ontogenetic stages as defined in this study seem to correlate with plant morphology, as we observed differences between the stages with regards to their allometry and variability in height and diameter, especially for E. edulis. This indicates that our classification is a useful tool for studying E. edulis and E. oleracea populations and their hybrids, thus enabling us to understand individual responses to their environment throughout their ontogeny. Young palms are usually overbuilt with respect to diameter growth before investing in height (Rich, 1987; Tomlinson, 2006), and, conversely, older palms cannot grow significantly in diameter as monocotyledon species do not have secondary growth (Rich, 1987). This is reflected in the allometry of our species, with older stages presenting higher allometric coefficients. It also explains the changes in variability of diameter and height, with younger stages being more variable for diameter than older stages, which are more variable for height.

Growth limitations also explain why allometric models proposed for neotropical and temperate forests (Dean and Long, 1986; Niklas, 1995) apply only partially to these palm trees. We observed that pooled data of E. edulis presented slopes higher than expected under geometric similarity. In order to maintain the elastic similarity, a safe proportionality against mechanical failure, stem diameter is expected to increase as a $3 / 2$ power of height (McMahon and Kronauer, 1976). Palms are not able to significantly increase in stem diameter, even though they keep growing in height. Alternatively, these species present a combination of attributes to ensure mechanical support: initial development of stem diameter for future support requirements, sustained cell expansion, and increasing stiffness and strength with age (Rich et al., 1986).

The absence of differences in the allometric model of the two Euterpe species indicates similar growth characteristics. The native E. edulis, the introduced E. oleracea and their hybrids presented allometric relationships either in accordance with the geometric growth model or more than it, i.e. taller than would be expected for this model. This supports our hypothesis that congener species tend to have similar characteristics of growth when they occur in the same environment. However, the allometric model 
observed for the population of E. oleracea introduced into the Atlantic rainforest is different from that observed for its populations in the Amazon Rainforest. In its original range, E. oleracea tends to present elastic similarity (Cole and Ewel, 2006). Therefore, although E. oleracea is able to establish in the Atlantic rainforest, there is clear evidence of environment-related phenotypic plasticity.

Size, pulp availability and amount of fruits produced are important in determining the plant's attractiveness to dispersers (Jordano, 2000). While our results indicate a higher production of fruits per stem by E. edulis, E. oleracea often has more than one reproductive stem at the same time, which may counterbalance the difference observed. In addition, the introduced palm, E oleracea, produced the same amount of pulp per fruit as the native palm species, but had slightly larger fruits and seeds and this could influence the disperser's choice (Jordano, 2000). Although hybrids also produced fruit, these fruits were significantly smaller than that of the original species and had significantly less pulp.

As expected from the similarity between the congener palm trees, E. edulis and E. oleracea (Henderson et al., 1995), both species produced similar seedlings, except for root weight and shoot:root ratio. With regards to intraparental variation in seedling morphometry, individuals of E. oleracea are more similar among them than those of E. edulis. This could be a result of the reduced genotypic variation of seeds of E. oleracea planted in the Atlantic rainforest. This can probably be explained by them having originated from a reduced sample of the original Amazonian population that was introduced in the Atlantic Rainforest, resulting in reduced genetic variability. This reduced variability could also be responsible for the lower germination rate of the exotic species.

Unlike E. edulis, the final size of E. oleracea seedlings was uncorrelated with the original size of the seed. This indicates that this species stops depending on the seed and starts using soil nutrients earlier, which is also shown by the higher production of roots by E. oleracea. Although the larger size of E. oleracea seeds did not result in improved growth, it seems to result in faster height gain. Two pieces of evidence confirm this hypothesis. First, the shoot:root ratio of E. oleracea was $50 \%$ larger than for E. edulis, meaning that for the same total weight, E. oleracea will have more shoot biomass and less root biomass than E. edulis. At this stage, it is expected that the seedling stops using seed resources for carbohydrate production and starts their production by its own photosynthesis (Green and Juniper, 2004). This would also explain the lack of correlation between seed and seedling weight. Second, as shown by allometry, seedlings of E. oleracea of a given diameter will be proportionally taller than seedlings of E. edulis. Larger seeds may also confer an advantage for growing in suboptimal circumstances, such as beneath the dense forest canopy. In this situation, having more reserves may allow a larger growth before the seedling runs out of reserves and starts depending uniquely on photosynthesis (Green and Juniper, 2004). Under deep shade conditions the taller E. oleracea would have some competitive advantage over $E$. edulis.

Our results indicate that E. oleracea, which is similar to E. edulis in aspects of allometry, development, seed and seedling morphology, may be an important competitor of this species. The similarity between the congener species, native E. edulis and introduced E. oleracea, may give the latter a greater ability in the use of resources than would be expected for an unrelated species. Fruits and seeds of E. oleracea were larger than those of E. edulis, but had a similar amount of pulp, and the faster height gain of its seedlings may confer them a competitive advantage in the field in spite of their lower germination rate. In conclusion, as E. oleracea is able to establish and also compete with the native E. edulis, the introduction of this species into the Atlantic rainforest should be discouraged.

Acknowledgements - We would like to thank FAPESP for scholarships provided for the first and third authors and CAPES for the second author. We would like to thank the Instituto Florestal for allowing our research in the State Park and APTA for providing the fruits used in this study.

\section{References}

BOVI, MLA., GODOY JUNIOR, G. and SAES, LA., 1987a. Híbridos interespecíficos de palmiteiro (euterpe oleracea $\mathrm{x}$ euterpe edulis). Bragantia, vol. 46, no. 2, p. 343-363.

-, 1987b. Pesquisas com os gêneros euterpe e bactris no iac. In I Encontro Nacional de Pesquisadores em Palmito, 1987. Curitiba: CNPF/EMBRAPA. p. 1-44.

CAMPOS, SDS., BOVI, MLA. and IADEROZA, M., 1991. Características do palmito obtido de algumas combinações híbridas entre açaí e juçara cultivadas sob diferentes condições. Pesquisa Agropecuária Brasileira, vol. 26, p. 637-646.

COLE, TG. and EWEL, JJ., 2006. Allometric equations for four valuable tropical tree species. Forest Ecology and Management, vol. 229, no. 1-3, p. 351-360. http://dx.doi.org/10.1016/j. foreco.2006.04.017

DEAN, TJ. and LONG, JN., 1986. Validity of constant-stress and elastic-instability principles of stem formation in pinus contorta and trifolium pratense. Annals of Botany, vol. 58, no. 6, p. 833-840.

DODONOV, P., LUCENA, IC., LEITE, MB. and SILVA MATOS, DM., 2011. Allometry of some woody species in a brazilian savanna after two years of a dry season fire. Brazilian Journal of Biology, vol. 71, p. 527-535. http://dx.doi.org/10.1590/ S1519-69842011000300025

GALETTI, M., ZIPPARRO, V. and MORELLATO, PC., 1999. Fruiting phenology and frugivory on the palm euterpe edulis in a lowland atlantic forest of brazil. Ecotropica, vol. 5, p. 115-122.

GATSUK, LE., SMIRNOVA, OV., VORONTZOVA, LI., ZAUGOLNOVA, LB. and ZHUKOVA, LA., 1980. Age states of plants of various growth forms: A review. Journal of Ecology, vol. 68, no. 2, p. 675-696. http://dx.doi.org/10.2307/2259429

GENINI, J., GALETTI, M. and MORELLATO, L., 2009. Fruiting phenology of palms and trees in an atlantic rainforest land-bridge island. Flora - Morphology, Distribution, Functional Ecology of Plants, vol. 204, p. 131-145. http://dx.doi.org/10.1016/j. flora.2008.01.002 
GREEN, PT. and JUNIPER, PA., 2004. Seed-seedling allometry in tropical rain forest strees: Seed mass-related patterns of resource allocation and the "reserve effect". Journal of Ecology, vol. 92, p. 397-408.

HAMMER, Ø., HARPER, DAT. and RYAN, PD., 2001. PAST: Paleontological statistics software package for education and data analysis. Palaeontologia Electronica, vol. 4, no. 1, p. 9. Available from: <http://palaeo-electronica.org/2001_1/past/issue1_01.htm>.

HENDERSON, A., GALEANO, G. and BERNAL, R., 1995. Field guide to the palms of the Americas. Princeton: Princeton University Press.

HOLMQUIST, JG., SCHMIDT-GENGENBACH, J. and SLATON, MR., 2010. Influence of invasive palms on terrestrial arthropod assemblages in desert spring habitat. Biological Conservation, vol. 144, no. 1, p. 518-525. http://dx.doi.org/10.1016/j. biocon.2010.10.007

JORDANO, P. 2000. Fruits and frugivory. In FENNER, M. (Ed.). Seeds, the ecology of regeneration in plant communities. Wallingford: CABI. p. 125-165. http://dx.doi.org/10.1079/9780851994321.0125

LEVINE, JM., VILÀ, M., D'ANTONIO, CM., DUKES, JS., GRIGULIS, K. and LAVOREL, S., 2003. Mechanisms underlying the impacts of exotic plant invasions. Proceedings Biological sciences/The Royal Society, vol. 270, p. 775-81. PMid:12737654 PMCid:1691311. http://dx.doi.org/10.1098/rspb.2003.2327

LORENZI, H., SOUZA, HMD., COSTA, JTM., CERQUEIRA, LSCD. and FERREIRA, E., 2004. Palmeira brasileiras e exóticas cultivadas. Nova Odessa: Instituto Plantarum de Estudos da Flora Ltda.

MANLY, BFJ., 2007. Randomization, bootstrap and monte carlo methods in biology. Boca raton: Chapman \& Hall/crc.

McMAHON, TA. and KRONAUER, RE., 1976. Tree structures: Deducing the principle of mechanical design. Journal of theoretical biology, vol. 59, no. 2, p. 443-466. http://dx.doi.org/10.1016/00225193(76)90182-X

MEYER, J-Y., LAVERGNE, C. and HODEL, DR., 2008. Time bombs in gardens: Invasive ornamental palms in tropical islands, with emphasis on french polynesia (pacific ocean) and the mascarenes. PALMS, vol. 52, no. 2, p. 23-35.

MOEGENBURG, SM. and LEVEY, DJ., 2003. Do frugivores respond to fruit harvest? An experimental study of short-term responses. Ecology, vol. 84, p. 2600-2612. http://dx.doi.org/10.1890/02-0063

MOONEY, HA. and CLELAND, EE., 2001. The evolutionary impact of invasive species. Proceedings of the National Academy of Sciences of the United States of America, vol. 98, p. 5446-51. PMid:11344292 PMCid:33232.

NIKLAS, KJ., 1995. Size-dependent allometry of tree height, diameter and trunk-taper. Annals of Botany, vol. 75, no. 3, p. 217-227. http://dx.doi.org/10.1006/anbo.1995.1015
-, 2004. Plant allometry: Is there a grand unifying theory? Biological reviews of the Cambridge Philosophical Society, vol. 79, p. 871-89. PMid:15682874. http://dx.doi.org/10.1017/S1464793104006499

R Development Core Team, 2011. R: A language and environment for statistical computing. Vienna: R Foundation for Statistical Computing.

RICH, P., 1987. Mechanical structure of the stem of arborescent palms. Botanical Gazette, vol. 148, no. 1, p. 42-50. http://dx.doi. org/10.1086/337626

RICH, PM., HELENURM, K., KEARNS, D., MORSE, SR., PALMER, MW. and SHORT, L., 1986. Height and stem diameter relationships for dicotyledonous trees and arborescent palms of costa rican tropical wet forest. Bulletin of the Torrey Botanical Club, vol. 113, no. 3, p. 241-246. http://dx.doi.org/10.2307/2996362

RICHARDSON, DM., PYSEK, P., REJMANEK, M., BARBOUR, MG., PANETTA, FD. and WEST, CJ., 2000. Naturalization and invasion of alien plants: Concepts and definitions. Diversity and Distributions, vol. 6, p. 93-107. http://dx.doi.org/10.1046/j.14724642.2000.00083.x

São Paulo. Secretaria de Defesa do Meio Ambiente - SDEDMA, 2008. Plano de manejo do parque estadual Carlos Botelho. São Paulo: Instituto Florestal. p. 546.

SILVA MATOS, DM. and BOVI, MLA., 2002. Understanding the threats to biological diversity in southeastern Brazil. Biodiversity and Conservation, vol. 11, p. 1747-1758. http:// dx.doi.org/10.1023/A:1020344213247

SILVA MATOS, DM., FRECKLETON, RP. and WATKINSON, AR., 1999. The role of density dependence in the population dynamics of a tropical palm. Ecology, vol. 80, p. 2635-2650.

SVENNING, J-C., 2002. Non-native ornamental palms invade a secondary tropical forest in Panama. PALMS, vol. 46, no. 2.

TOMLINSON, PB., 2006. The uniqueness of palms. Botanical Journal of the Linnean Society, vol. 151, no. 1, p. 5-14. http:// dx.doi.org/10.1111/j.1095-8339.2006.00520.x

TUCIC, B., DUCIC, J. and PEMAC, D., 2006. Phenotypic responses to early signals of neighbour proximity in picea omorika, a pioneer conifer tree. Basic and Applied Ecology, vol. 7, no. 5, p. 443-454. http://dx.doi.org/10.1016/j.baae.2005.06.006

WARTON, D., 2007. Smatr: (Standardised) major axis estimation and testing routines. R package version 2.1.

WARTON, DI., WRIGHT, IJ., FALSTER, DS. and WESTOBY, M., 2006. Bivariate line-fitting methods for allometry. Biological Reviews, vol. 81, no. 2, p. 259-291. PMid:16573844. http://dx.doi. org/10.1017/S1464793106007007

WEINER, J., 2004. Allocation, plasticity and allometry in plants. Perspectives in Plant Ecology, Evolution and Systematics, vol. 6, no. 4, p. 207-215. 